\title{
Conceptualising Conscientious Objection as Resistance ${ }^{1}$
}

\author{
Dr Benjamin Farrand, Lecturer in Intellectual Property Law and Policy, University of \\ Strathclyde, School of Law, University of Strathclyde, 50 Graham Hills Building, George \\ Street, Glasgow G1 1QE \\ Benjamin.farrand@strath.ac.uk
}

\begin{abstract}
While conscientious objection in healthcare is becoming increasingly studied, the legislative implementation of the principle is often without definition, leading to the question 'what is conscientious objection?' As this article will demonstrate, it is useful to reconceptualise conscientious objection as 'resistance' to dominant discourses and understandings in society, which have been internalised and co-opted as a way of acting as a 'safety-valve' for individualised dissent, as well as reinforcing perceptions of freedom, choice and tolerance in liberal democratic society. This non-normative assessment of conscientious objection therefore seeks to provide a framework for understanding why certain forms of resistance may be considered conscientious and some may not, before then applying this understanding to issues such as abortion and female genital mutilation.
\end{abstract}

\section{Introduction}

Conscientious objection in healthcare is a concept that is well established and legally recognised. In 2010, the Council of Europe's Parliamentary Assembly recognised the right to conscientious objection in healthcare, stating in a Resolution that Member States should 'guarantee the right to conscientious objection in relation to participation in the medical procedure in question'2. However, legislation enshrining a right to conscientious objection does not define it, and Campbell states that conscientious objection in healthcare can be defined as a refusal to perform, participate in or contribute to a certain procedure in a

\footnotetext{
${ }^{1}$ I wish to thank Dr Mary Neal at the University of Strathclyde for providing useful comments and advice in the drafting of this article.

${ }^{2}$ Council of Europe Parliamentary Resolution 1763 (2010) The right to conscientious objection in lawful medical care, (7 October 2010) paragraph 4.1
} 
personal capacity on the basis of a belief that there is a moral obligation to not perform that procedure ${ }^{3}$. Yet is such an understanding sufficient? Are all refusals to perform based on a moral imperative conscientious? How do we determine what objections are conscientious, and which are unacceptable?

The purpose of this article is to examine this question in more detail, and thereby reconceptualise conscientious objection in terms of 'resistance'. By using a Foucauldian framework in which dominant discourses are linked to power, it will be demonstrated that conscientious objection constitutes resistance against a dominant way of thinking within society, and as such, cannot be divorced from the social, cultural and historical context in which that act takes place. To put it another way, what may be considered a 'conscientious' objection in one state or culture may be considered unconscionable behaviour in another. The intention, therefore, is not to make any normative statements about conscientious objection, and whether it should be permissible, but to provide an explanation as to why some types of behaviour may be considered as 'conscientious', and why some may not. Finally, this analytic framework will then be applied to debates over medical procedures that may be considered socially accepted, such as abortion, and those largely considered abhorrent, such as female circumcision.

\section{Networks of Power, Networks of Resistance: A Framework for Conceptualising Conscientious Objection}

Before entering into the discussion of conscientious objection as a form of resistance, it is first necessary to expand upon the concepts of power and resistance as defined by Foucault. For Foucault, the purpose of his work on power was to 'determine what are, in their mechanisms, effects, their relations, the various power-apparatuses that operate at various levels of society..." ${ }^{4}$. The intent, therefore, was not to provide for a theory of power, but a way of analysing power relations ${ }^{5}$. Foucault determined that it was not useful to think of

\footnotetext{
${ }^{3}$ Mark Campbell, 'Commentary: Conscientious Objection and the Council of Europe', Medical Law Review 19, no. Summer (2011): 472.

${ }^{4}$ Michel Foucault, Society Must Be Defended: Lectures at the Collège de France, 1975-76, trans. David Macey (London: Penguin, 2004), 13.

${ }^{5}$ Michel Foucault, Remarks on Marx: - Conversations with Duccio Trombadori, trans. R. James Goldstein and James Cascaito (New York: Semiotext(e) Foreign Agents, 1991), 148; see also Mark G. E. Kelly, The Political Philosophy of Michel Foucault (London: Routledge, 2012), 34-35.
} 
power within society functioning in a 'juridical' sense, in which power is something that can be possessed, bartered and transferred6, but as a relational force. 'Power is not something divided between those who have it and hold it exclusively, and those who do not have it and are subject to it. Power must...be analysed as something that circulates...exercised through networks'7. As Downing states, the effects of power are 'not exercised from a single vantage point, but are mobile [and] multivalent'8, indicating that power is something multilateral, exercised and influencing in different ways. Legal power, for example, may operate through the judge sentencing the convicted to a seven-year prison sentence. But this power is not held by a judge, the power to solely incarcerate or to punish, to release or pardon. Instead, this power is something exercised by a judge by virtue of their office. This type of power can be referred to as 'governmentality' - the 'ensemble formed by the institutions, procedures, analyses, and reflection, the calculations and tactics that allow the exercise of this very specific, albeit complex form of power'9. Butler states that 'marked by a diffuse set of strategies and tactics, governmentality gains its meaning and purpose from no single source, no unified sovereign subject'10. In other words, the power exercised by a judge comes from a multitude of different sources, interacting in such a way as to make that exercise of power possible. The judge cannot choose an individual at random, and order their imprisonment. The judge instead is empowered through the legitimacy granted to their actions through the creation of legislation that states that the committal of certain offences will result in incarceration. Yet, this legislation may have arisen as the result of changing social norms, in which a certain form of conduct was perceived to be undesirable, and therefore should be punished. In turn, the convincing case brought by prosecutors may have convinced a jury that a guilty verdict is the correct one. The judge, acting on the findings of the jury, and conscious of media attention and discussions of lax sentencing, then orders the maximum sentence be applied. Power has operated within a network, in which different individuals or institutions have in turn exercised power to influence the decisions of other individuals or institutions. The relationship between state institutions such as government and groups or individuals is multi-directional, including the relations between government and social

\footnotetext{
${ }^{6}$ Foucault, Society Must Be Defended, 13.

7 Ibid., 24.

${ }^{8}$ Lisa Downing, The Cambridge Introduction to Michel Foucault (Cambridge: Cambridge University Press, 2008), 83.

${ }^{9}$ Michel Foucault, Power: The Essential Works of Michel Foucault 1954-1984, ed. James Faubion, vol. 3 (London: Penguin, 2002), 219-220.

10 Judith P. Butler, Precarious Life: The Power of Mourning and Violence (London: Verso Books, 2004), 52.
} 
institutions, or relations concerning political sovereignty ${ }^{11}$. Governmentality then asks 'by what means, mechanisms, procedures, instruments, tactics, techniques, technologies and vocabularies is authority constituted and rule accomplished?'12.

Central to power is knowledge. Or, to put it another way, that 'knowledge and power are integrated with one another...it is not possible for power to be exercised without knowledge, it is impossible for knowledge not to engender power'13. According to Foucault, 'the delicate mechanisms of power cannot function unless knowledge, or rather, knowledge apparatuses, are formed, organized and put into circulation'14. This means that knowledge production is the result of the exercise of power, and in turn, knowledge then facilitates the exercise of power. To give an example, an expert panel is formed, comprising international business leaders. This panel concludes that the best way to ensure growth is through the removal of any regulations that hinder the inexpensive manufacture of consumer goods, whether that relates to employment protections, health and safety regulations or customs duties. The panel produces a report that is then passed to national governments. Given the perceived expertise of this panel, national governments embark on a deregulation agenda. That the body was made of experts gives weight to the claim that a particular policy is required - that policy is required, because it was made by an expert body. The policy agenda therefore produces knowledge that indicates that the body in question was an expert one. In this way, knowledge defines the 'objects of such practices, codifies appropriate ways of dealing with them, set the aims and objectives of practice, and define the professional and institutional locus of authoritative agents of expertise'15. Because this body has been deemed as 'expert', its claims are then reported as such by governments and the media. This discourse, that dictates regulation is interfering with growth, becomes accepted as 'truth'. According to Shiner, "truth" is centred on scientific discourse and institutions; it is central to economic production and political power...produced and disseminated by great economic and political apparatuses like the university, or media...'16. When these 'truths' become accepted, they

\footnotetext{
${ }^{11}$ Colin Gordon, 'Governmental Rationality: An Introduction', in The Foucault Effect: Studies in Governmentality, ed. Graham Burchell, Colin Gordon, and Peter Miller (Chicago: University of Chicago Press, 1991 ), 3.

12 Mitchell Dean, Governmentality: Power and Rule in Modern Society, 2nd ed. (London: SAGE, 2010 ), 42.

13 Michel Foucault, Power/Knowledge: Selected Interviews and Other Writings, 1972-77, ed. Colin Gordon (London: Harvester Press, 1980), 51.

14 Foucault, Society Must Be Defended, 33-34.

15 Dean, Governmentality, 32.

${ }^{16}$ Larry Shiner, 'Reading Foucault: Anti-Method and the Genealogy of Power-Knowledge', History and Theory 21, no. 3 (1 October 1982): 384
} 
become a dominant discourse, hegemonic, 'incorporated into the common-sense way we interpret, live in, and understand the world'17. They are not regularly challenged, or brought into question, because to do so questions the way in which the world is perceived to work. In twenty-first century Europe, for example, the right of women to vote is not seen as controversial - it is a commonly accepted and normalised practice, based on the understanding that men and women are equally entitled to determine who may govern. Similarly, throughout the eighteenth and nineteenth centuries certain discourses became dominant, and truths 'accepted', about the practice of medicine. Medical science became understood not as a loose 'group of traditions, observations, and heterogeneous practices, but as a corpus of knowledge that presupposed the same way of looking at things...a group of hypotheses about life and death, of ethical choices, of therapeutic decisions, of institutional regulations...'18. In turn, doctors becomes endowed with a certain status, based on perceptions of 'competence and knowledge; institutions, systems, pedagogic norms; legal conditions that give the right - though not without laying down certain limitations - to practice and to extend one's knowledge'19.

This is not to say that because a particular view or understanding is dominant within a society, it is completely accepted by all members of society. To take the example of universal suffrage, extreme political conservatives may argue that a traditional society with clearly defined gender roles functions more effectively, and that men should vote but women should not. As Foucault put it, 'there is no power without potential refusal or revolt.'20 Where there is power, there is the possibility of resistance, for if power is the exercise of influence through social relations, then the exercise of power through social relations can also be used to resist. Or, as Kelly puts it, since 'power is everywhere in society, it means that resistance is everywhere too'21. To give another example, a student is talking in class. The teacher ordering the student to stop talking is an exercise of power; rather than stop, however, the student talks more loudly than before. This act of resistance also constitutes an exercise of power. Nevertheless, although all actors within a network may exercise power, the ability to exercise power effectively is inegalitarian, and some nodes are more able to influence than

\footnotetext{
17 David Harvey, 'Neoliberalism as Creative Destruction', The ANNALS of the American Academy of Political and Social Science 610, no. 1 (3 January 2007): 23.

18 Michel Foucault, Archaeology of Knowledge, 2nd ed. (London: Routledge, 2002), 36-37.

19 Ibid., 55-56.

${ }^{20}$ Foucault, Power, 3:324.

${ }^{21}$ Kelly, The Political Philosophy of Michel Foucault, 107.
} 
others due to privileged positions ${ }^{22}$ - in this instance, the loud student may be sent out of the room, or to the principal. Again, resistance like power is relational; 'the specific character of resistance is itself influenced by the power it opposes'23. In other words, resistance is a response to the exercise of power. This resistance can be characterised as 'macro' or 'micro' resistance. Macro resistance refers to great ruptures, or fundamental shifts in networks of power. Examples of this may include the French Revolution, for example, and the (at least temporary) removal of unelected Kings in favour of a Republic, or the changes in Russia post-1917 creating a Communist state. A less extreme example may include the repeal of a highly contentious piece of legislation, such as the apparent repeal of the Data Retention Directive $^{24}$ through a declaration by the Court of Justice of the European Union that as a result of the disproportionate nature of the Directive, it was therefore invalid and unenforceable 25 . Micro resistance, however, is resistance on a more local, individual level. This could be considered as the simple act of saying 'no'. It could include the child refusing to go to bed at the hour decided by the child's parents, or the woman who refuses to turn off her mobile phone in the cinema. They are acts of resistance on an individual level, indicating a refusal to be bound by, or at the least a refusal to accept, a particular command, decision or law. As Kelly states, these are acts of resistance that do constitute an exercise of power, in the form of a refusal to act or insistence upon acting by the individual that nevertheless present 'no overall conflict with the network of power relations' 26 . The child refusing to go to bed does not successfully challenge the understanding that it is the parents that make the rules concerning the conduct of the child. The woman refusing to turn off the phone does not result in a change of dominant discourse and social norm that phones should be switched off in movie theatres. Localised, micro-resistance can not only result in disciplinary action based in the existing networks of power (the child is grounded, the woman 'socially shamed' or even asked to leave the cinema), but can also be co-opted, or factored into the existing networks of power. One example includes punk music - initially considered a social ill and associated with moral panics due to its 'proclamation and

\footnotetext{
22 Ibid., 41; Thomas Lemke, Foucault, Governmentality, and Critique (Colorado: Paradigm, 2011), 19-20.

${ }^{23}$ Kelly, The Political Philosophy of Michel Foucault, 108.

24 Directive 2006/24/EC of the European Parliament and of the Council of 15 March 2006 on the retention of data generated or processed in connection with the provision of publicly available electronic communications services or of public communications networks and amending Directive 2002/58/EC [2006] OJ L 105/54

25 Joined Cases C-293/12 and C-594/12 Digital Rights Ireland Ltd v Minister for Communications, Marine and Natural Resources and others, 8 April 2014

${ }^{26}$ Kelly, The Political Philosophy of Michel Foucault, 110.
} 
embrace of discord...Early punk sought to tear apart consumer goods, royalty, and sociability; it sought to destroy the idols of the bourgeoisie'27. However, by 2014, punk is just another musical and social sub-culture, one of many different forms of performance associated with an acceptable frame of teenage rebellion or social commentary - 'a relatively stable niche in which there is no overall conflict with the network of power relations'28. In this way, resistance can be accepted and factored into existing discourses, allowing for a form of societal 'safety valve', in which individual acts of resistance prevent larger, more concentrated and organised forms of resistance that threaten the existing structures and discourses.

\section{Conscientious Objection as a Form of Resistance: The Challenging of Dominant Discourses in the Provision of Healthcare in Contentious Fields}

Based on the preceding section, this section will seek to demonstrate that a useful way of conceiving conscientious objection is as a form of micro-resistance. Groups or individuals choose to say 'no' in response to the exercise of power that comes through the existence of social norms or overarching understandings of the world apparent in dominant discourses, as well as hegemonic discourses concerning medical treatment and the medical profession specifically. The interaction between these discourses, in which dominant social attitudes become buttressed by a discourse of medical and scientific rationalism then create the conditions in which resistance not only occurs, but can be co-opted as an acceptable form of dissent.

\subsection{Choice, Rights, Freedom: Societal Discourses Impacting Upon Medical Treatment}

The discourse, and indeed academic discussion, of conscientious objection in healthcare generally takes place within the framework of Western liberal democracy. As such, there are certain norms and principles that emanate from this system of government that are so commonly accepted to the extent that they are taken for granted as the way in which the world functions. However, by exploring them in more detail, it may help in the

\footnotetext{
${ }^{27}$ Dylan Clark, 'The Death and Life of Punk, the Last Subculture', in The Post-Subcultures Reader, ed. David Muggleton and Rupert Weinzierl (New York: Berg, 2003), 225.

${ }^{28}$ Kelly, The Political Philosophy of Michel Foucault, 110.
} 
conceptualisation of conscientious objection. In the system of liberal democracy, 'the freedom of individuals is regarded as a critical yardstick for governmental action'29. Freedom therefore constitutes a hegemonic characteristic in liberal democracies, often juxtaposed against those nations or political systems in which citizens are not considered to 'be free'. In this conception, 'individual freedom represents a technical condition of rational government'30. Limitations on freedom, therefore, must serve a rational function, such as to protect the freedom of others - incarcerating those who have committed violent crime, so as to prevent them committing further crimes against citizens. The limits of these freedoms, within a liberal system, are ostensibly those decided by citizens through the act of representative or participatory democracy, based on the dominant social norms of that time - 'society comes first, law and government later'31. Associated, or even interlinked with this notion of individual freedom within a system of liberal democracy are the notions of choice and rights. Particularly in the light of the economic policies pursued by Thatcher and Reagan in the 1980s, conceptions of liberty have been associated with market-based logics and the right to choose. In particular, as Miller and Rose indicate, since the 1980s the importance and general social acceptance of the value of individual freedom, personal choice and selffulfilment has become apparent ${ }^{32}$.

Yet how does this apply to conscientious objection in healthcare? The answer is that conscientious objection must be understood in the context of the dominant discourses within the society in which it is assessed. As literature in the field of conscientious objection in healthcare indicates, the discourses of freedom, choice and rights features prominently. Antommaria refers to the framing of debates over certain medical treatments as adjudicating between 'patients' right to legally available medical treatments versus health care providers' right to refuse to participate in any intervention they find morally objectionable'33. Wicclair uses a similar rights-based discourse, discussing 'two important rights at stake: rights of conscience and a right of access to healthcare without undue burdens'34. Vischer in turn

\footnotetext{
${ }^{29}$ Lemke, Foucault, Governmentality, and Critique, 15.

${ }^{30}$ Ibid., 16.

31 Dean, Governmentality, 147.

32 Peter Miller and Nikolas Rose, Governing the Present: Administering Economic, Social and Personal Life (Cambridge: Polity Press, 2008), 30-52.

${ }^{33}$ Armand H Matheny Antommaria, 'Adjudicating Rights or Analyzing Interests: Ethicists' Role in the Debate over Conscience in Clinical Practice', Theoretical Medicine and Bioethics 29, no. 3 (2008): 202.

${ }^{34}$ Mark R Wicclair, 'Is Conscientious Objection Incompatible with a Physician's Professional Obligations?', Theoretical Medicine and Bioethics 29, no. 3 (2008): 173.
} 
analyses the interaction between rights of access 'versus' institutional identity as it pertains to the provision of emergency contraception in the form of the morning-after pill ${ }^{35}$, whereas in discussing new technologies associated with childbirth, Robertson refers to 'procreative freedom', or 'the freedom to reproduce or not to reproduce'36. Indeed, with the advancement of women's rights and feminism as a movement, the ability of a woman to choose what happens with her body, including the right to decide to terminate a pregnancy, is increasingly an accepted concept in liberal democracies. The passing of the Abortion Act 1967 in the UK, referred to as 'liberal' by Cook and Dickens ${ }^{37}$, and decisions such as Roe $v$ Wade in the US ${ }^{38}$ marked the beginning of the liberalisation of laws relating to abortion, indicating according to Cook et al. that liberal democracies have been reforming their abortion laws 'in conformity with human rights principles respectful of women's human rights to life, health, and reproductive self-determination'39. Supporting this view is the Canadian case of $R v$ Morgentaler ${ }^{40}$, in which the Chief Justice of Canada stated that forcing a woman to carry a foetus to term 'unless she meets certain criteria unrelated to her own priorities and aspirations, is a profound interference with a woman's body and thus a violation of security of the person'41. It is submitted that this statement effectively fits within a discourse of freedom, choice and rights, and has been influenced by the dominant discourse in that particular society - as such, the law has followed the development or change in networks of power in that social context.

In a society in which the dominant or accepted 'truth' is that there must be respect for this personal autonomy, the right of a woman to choose what happens to her body, then conscientious objection in this context is the rejection of that 'truth', and resistance to the exercise of power that states that this freedom to choose should be respected by medical practitioners. After all, as Savulescu has infamously stated, 'what should be provided to patients is defined by law...if people are not prepared to offer legally permitted, efficient, and

\footnotetext{
${ }^{35}$ Robert K. Vischer, 'Individual Rights vs. Institutional Identity: The Relational Dimension of Conscience in Health Care', Ave Maria Law Review 9 (2010): 67.

${ }^{36}$ John A Robertson, Children of Choice: Freedom and the New Reproductive Technologies (Princeton: Princeton University Press, 1994), 22.

${ }^{37}$ Rebecca J. Cook and Bernard Dickens, 'Human Rights and Abortion Laws', International Journal of Gynecology \& Obstetrics 65 (1999): 83.

${ }^{38}$ Roe v. Wade, 410 U.S. 113 (1973)

${ }^{39}$ Rebecca J. Cook, Mónica Arango Olaya, and Bernard M. Dickens, 'Healthcare Responsibilities and Conscientious Objection', International Journal of Gynecology \& Obstetrics 104, no. 3 (March 2009): 249.

4044 DLR (4th) 385, Supreme Court of Canada (1988)

41 Ibid at 402
} 
beneficial care to a patient because it conflicts with their values, they should not be doctors'42. While perhaps something of a strong position, it nevertheless reflects the dominant discourse in liberal democracies that the right of individuals to choose (whether as patients or as consumers) either should not be interfered with, or alternatively, should be interfered with only to the extent that is necessary to achieve another socially-desirable goal. Conscientious objection to the provision of certain medical procedures is resistance to this discourse. Does it mean that resistance in this form is free from dominant discourses or power relations that influence the decision making of individuals? The answer is no; instead, it means that the individual resisting that discourse is nevertheless subject to another discourse that through a process of internalisation, becomes the accepted 'truth'. This can be referred to as 'ethics' in the Foucauldian sense, 'the elaboration of a form of selfrelation that enables the individual to constitute himself as the subject of moral conduct'43. This may be the result of the imposition or influence of an external code, which is then subsumed as part of the identity of that individual. One example of this is religious codes, which appear to have an influence on the decision of individuals to resist accepted medical practices. In an analysis of reasons why pharmacists in the State of Nevada were unwilling to distribute emergency contraceptives or medical abortifacients, 'religion emerged as a significant predictor...Evangelical Protestant, Catholic and "Other Religious" pharmacists were significantly less likely to dispense medications while non-religious pharmacists were significantly more willing'44. As Curlin et al. discuss, many of the areas of medical practice that clinicians may object to are prominently those that concern the sexual and reproductive health of women (end of life issues being the noticeable exception), and those objection to the provision of those services predominantly identify as religious - and it is those same physicians 'who are most likely to be asked to act against their consciences are the ones who are most likely to say that physicians should not have to do so'45. Here we see that a predominant conflict is between the dominant discourse within society at a general level, in terms of the social norms and accepted cultural practices - i.e. freedom, and the right to choose, and that of a rival node within that social network, namely the religious code

\footnotetext{
42 Julian Savulescu, 'Conscientious Objection in Medicine', British Medical Journal 332 (2006): 294.

43 Michel Foucault, The History of Sexuality Volume 2: The Use of Pleasure, trans. Robert Hurley (New York: Pantheon, 1985), 251.

${ }^{44}$ Laura A. Davidson et al., 'Religion and Conscientious Objection: A Survey of Pharmacists' Willingness to Dispense Medications', Social Science and Medicine 71 (2010): 154.

45 Farr A. Curlin et al., 'Religion, Conscience, and Controversial Clinical Practices', New England Journal of Medicine 356, no. 6 (2007): 597.
} 
constituting part of the clinician's identity that dictates a refusal to accept that socially accepted 'truth'. They choose to resist that influence or exercise of power that compels them to perform a particular service, on the basis that it conflicts with their self-constitution as a moral actor based on the internalization of a religious code. Yet it is not sufficient to base an understanding of conscientious objection on the level of society alone; we must also consider the communities of practice in the field of medicine, and the dominant discourses that operate within that network.

Doctors, and indeed nurses, pharmacists, and medical researchers all constitute what can be referred to as communities of practice ${ }^{46}$. A community of practice is a group of people engaged in a particular activity that frequently communicate with each other about these activities. Doctors, through the process of professionalisation in the late nineteenth century, emerged as such a group ${ }^{47}$. Furthermore, doctors in particular function as an epistemic community. An epistemic community, according to Haas, constitutes 'a network of professionals with recognised expertise and competence in a particular domain and an authoritative claim to policy relevant knowledge within that domain or issue-area...'48. As mentioned in the second section of this article, power, and by extension policy development, depends substantially upon these perceptions of expertise and the production of knowledge. As a community of actors with an ostensible shared purpose and claims to expert knowledge, medical practitioners as a group are able to influence both public perceptions of medical treatment, as well as specific laws concerning medical practice. Again, using the example of the nineteenth century, doctors as an epistemic community were instrumental in the restriction of access to abortion in the $\mathrm{UK}$ and the increase in criminal sanctions for performing the procedure ${ }^{49}$. In turn, doctors were consulted and actively involved in the reframing of abortion in the twentieth century as an issue about the healing of women, and the permissibility of abortion for therapeutic reasons ${ }^{50}$. However, just as the medical profession is able to influence discourses regarding medical treatment, so too is the medical

\footnotetext{
46 Jean Lave and Etienne Wenger, Situated Learning: Legitimate Peripheral Participation (Cambridge [England]; New York: Cambridge University Press, 1991).

${ }^{47}$ See generally John Keown, Abortion, Doctors, and the Law: Some Aspects of the Legal Regulation of Abortion in England from 1803 to 1982 (Cambridge; New York: Cambridge University Press, 1988); Michael Thomson, 'Abortion Law and Professional Boundaries', Social and Legal Studies 22 (2013): 193.

48 Peter M. Haas, 'Introduction: Epistemic Communities and International Policy Coordination', International Organization 46, no. 1 (1 January 1992): 3.

49 Thomson, 'Abortion Law and Professional Boundaries', 195-196.

50 Ibid., 207.
} 
profession influenced by dominant discourses pervading society at a particular time. As a result, what constitutes proper medical treatment or 'acceptable science' is largely dependent on the social and cultural conditions in which that treatment takes place. For example, during the late nineteenth and early-to-mid twentieth century, the study of eugenics was commonly accepted as acceptable science, in which some races were deemed to be degenerate and a threat to the preservation of mankind ${ }^{51}$. The common acceptance of these theories at a social level was influenced by the scientific discourses of 'expert men', which in turn reinforced the claims to expertise that those men possessed. The common acceptance of these theories, as we are well aware, has led to some of the greatest atrocities of the twentieth century. As Foucault argued, this discourse maintained that the death of the bad race, of the inferior race (or the degenerate or the immoral) is something that will make life in general healthier: healthier and purer'52. When such a discourse becomes socially accepted, it can then be used to justify medical treatments and procedures such as sterilisation, or worse. Nevertheless, contemporary scientists would largely agree that eugenics as understood in the early twentieth century amounted to no more than 'pseudoscience', bearing little relation to what is currently understood as scientific thought. This demonstrates that as with more general views on society and how society should be governed, medical discourses too are subject to change - what is considered scientific now may not be considered scientific tomorrow. Indeed, science, as with social attitudes, are changeable, and dependent upon the culture and dominant discourses in which it exists.

\subsection{Conscientious Objection Conceptualised and the Co-Option of Resistance}

The previous sections have determined that one way of conceptualising conscientious objection is as a form of resistance against dominant discourses, either at a general societal level, or alternatively, within the context of the discourse of medical professionals as a community. It is submitted that by conceptualising conscientious objection in such a manner, it is possible to then consider the bounds of conscientious objection with regard to power relations in order to determine what may constitute conscientious objection and what may not. As demonstrated by the above subsections, as discourses may change with changes in society, so too may what constitutes conscientious objection. This may be

\footnotetext{
51 Dean, Governmentality, 158-162.

52 Foucault, Society Must Be Defended, 255.
} 
expressed in the following way: there must be something to resist, to necessitate resistance. Another way of phrasing this is that there must be something to object to for conscientious objection to be necessary. To provide an example, with the professionalisation of doctors in the nineteenth century, abortion was instrumentalised as a way of building a perception of elite status and ethical standing53. Within the epistemic shift and development discourse in which abortion was deemed socially unacceptable, a doctor refusing to provide that service would not be engaged in conscientious objection. There would be no resistance, as they were operating within the dominant discourse, reinforcing the existing power structures in which abortion was prohibited. In turn, when dominant social discourses changed, reflecting social norms concerning freedom, individualism and the right to choose, approaches to abortion were liberalised. The refusal to participate in what became liberalised and both socially acceptable and legally possible constitutes an act of resistance, as it challenges, albeit on an individual level, those existing power structures and the discourse that such action is permissible. To provide a different example, let us take the example of female circumcision, also commonly referred to as female genital mutilation. Female genital mutilation causes significant emotional responses, and is generally viewed with abhorrence in liberal democracies. The World Health Organisation has referred to the practice as reflecting 'deep rooted inequality between the sexes, and constitutes an extreme form of discrimination against women'54. In the UK, the practice is explicitly illegal as a result of the Female Genital Mutilation Act 2003 in England, Wales and Northern Ireland, and the Prohibition of Female Genital Mutilation (Scotland) Act 2005, both of which not only prohibit the practice in the UK, but also for UK nationals to perform the procedure outside the $\mathrm{UK}^{55}$, carrying a maximum penalty of fourteen years. It is highly unlikely therefore that a doctor refusing to perform the procedure in the UK would be regarded as conscientiously objecting - the social norm and dominant discourse stating that such conduct is reprehensible, and to object to it would not be viewed as conscientious, merely refraining from doing something society has deemed it wrong to do. That person has chosen not to engage in conduct considered sufficiently serious that engaging in it would be considered illegal. In comparison, the individual who attempts to perform that procedure can be

\footnotetext{
53 Thomson, 'Abortion Law and Professional Boundaries', 195.

${ }^{54}$ World Health Organisation, Eliminating Female Genital Mutilation: An Interagency Statement, (Geneva: WHO Press 2008), 1

55 Female Genital Mutilation Act 2003, s.4 and Prohibition of Female Genital Mutilation (Scotland) Act 2005 s.4 respectively
} 
considered as engaging in resistance. It is a rejection of the liberal democratic discourse concerning the act as a criminal offence, and a statement that a practice should be permitted on the basis of the cultural beliefs that make such conduct not only acceptable, but important as a right of passage into 'womanhood'56. Indeed, in countries in which this practice is normalised, this discourse is dominant at the social level and the prevalence of female genital mutilation is as high as $85 \%$ of the female population ${ }^{57}$, it is the medical professional that refuses to perform such practices that is engaged in resistance.

Yet it would cause considerable consternation (to say the least), should it be argued in a Western liberal democracy that the act of performing female genital mutilation would be considered an act of conscientious objection. In comparison, it may well be agreed upon that the act of refusing to perform that act in a country in which it is commonly accepted is an act of conscientious objection. Within this framework of analysis, how may those two different acts be distinguished? It is submitted that the answer again lies within analysis of dominant discourses, and in the incorporation, or co-option of resistance. If we return to the subject of abortion, with the liberalisation of laws came specific conscientious objection clauses. For example, the Abortion Act 1967 states at s.4(1) that 'no person shall be under any duty, whether by contract or by any statutory or other legal requirement, to participate in any treatment authorised by this Act to which he has a conscientious objection'. In the US, according to Charo, 45 states have conscience clauses ${ }^{58}$. As this demonstrates, resistance has been specifically permitted, in the case of individuals who do not want to participate in actions though deemed socially acceptable they nevertheless regard as undesirable or repugnant to their sensibilities. Linked to the understanding that in liberal democracy choice, freedom and rights are commonly accepted 'truths', is the understanding that freedom and choice involves respecting the rights and beliefs of others, which can be considered a discourse of tolerance. The incorporation of resistance in this context is the acceptance of the right of individuals to also choose not to participate in certain procedures. Wicclair, for example, refers to conscientious objection being generally accepted in the

\footnotetext{
${ }^{56}$ See P Stanley Yoder, Papa Ousmane Camara, and Baba Soumaoro, Female Genital Cutting and Coming of Age in Guinea (Conakry, Guinea, December 1999), 14, Conakry, Guinea.

57 World Health Organisation, Eliminating Female Genital Mutilation: An Interagency Statement, 6, in which it stated that this practice has near universal prevalence (above 85\%) in seven countries, high prevalence (between 60-85\%) in four countries, and medium prevalence (30-40\%) in seven countries

${ }^{58} \mathrm{R}$ Alta Charo, 'The Celestial Fire of Conscience - Refusing to Deliver Medical Care', The New England Journal of Medicine 352, no. 24 (2005): 2471.
} 
medical community, referring to the American Medical Association guidelines stating that medical schools should have mechanisms in place for allowing students to be excused from activities that violate students' religious or ethical beliefs ${ }^{59}$. Similarly, many authors on conscientious objection argue within a discourse of tolerance, favouring the right of individual practitioners to opt out of providing treatments they oppose, generally so long as they refer the patient to someone who will provide that treatment ${ }^{60}$. Such an approach allows for conscientious objection to act as a 'safety-valve', allowing for an individualised resistance to abortion that does not threaten the overall networks of power, as the individual ability to refuse may help to limit the potential for organised movements developing to attempt to challenge the existing power structures in which abortion is tolerated. So long as there is referral, meaning that the individualised resistance does not impact upon the freedom or choice of others, then this is to be tolerated within a liberal democratic framework. Even Savulescu, who voiced a strong opinion about conscientious objection nevertheless argued that where there are a sufficient number of practitioners willing and able to provide a service 'there is an argument for allowing a few to object out'61. This acceptance of resistance, in the form of conscientious objection, therefore fits within the discourse of choice and freedom that is hegemonic within liberal democratic societies. These forms of resistance are permitted, because they allow the exercise of choice in a way that does not unduly limit the choices of others. They choose not to act, in their form of resistance. The person who performs a female circumcision, in comparison, is perceived to act in a way that limits choice, or acts in a way demonstrating a significant power imbalance, with women perceived as victims, not patients ${ }^{62}$. By the standards of contemporary liberal democracies, this means that performing female circumcision cannot be conscientious. In a country such as Burkina Faso, for example, where the prevalence of female circumcision was estimated to be $73.0 \%$ in 200163 , it is the practitioner who refuses to perform the procedure who resists. By the standards of liberal democracy, given the perception of the woman as victim, deprived of choice, the resistance constitutes conscientious objection. By the standards of Malian society, in comparison, this practice is considered as acceptable and

\footnotetext{
59 Wicclair, 'Is Conscientious Objection Incompatible with a Physician's Professional Obligations?', 180.

${ }^{60}$ See for example Vischer, 'Individual Rights vs. Institutional Identity', 74-77; Mark R Wicclair, 'Conscientious Objection in Medicine', Bioethics 14, no. 3 (2000): 206; Adrienne Asch, 'Two Cheers for Conscience Exceptions', Hastings Center Report November-December (2006): 11.

61 Savulescu, 'Conscientious Objection in Medicine', 296.

62 World Health Organisation, Eliminating Female Genital Mutilation: An Interagency Statement, 1

63 UNICEF, 'Female Genital Mutilation/Cutting: A statistical exploration', UNICEF Press (2005), 35
} 
something that should continue, with $80 \%$ of women believing the practice should continue ${ }^{64}$, with $69.9 \%$ of women and $63.2 \%$ of men citing religious demands as the reason $^{65}$. In this context, the practitioner may not be perceived as a conscientious objector, but someone who interferes with religious requirements. Similar arguments can be found within the European Union, and demonstrate that conceptualisations of conscientious objection cannot be divorced from conceptualisations of power. For example, postCommunist Poland saw an increase in the influence of the Catholic Church in political matters, coupled with a conservative yet neoliberal social policy pursued by successive governments. Abortion, which was once legally sanctioned, became increasingly restricted, and subject to a conscience clause that permitted a doctor to refuse to perform the procedure66. In a telling interview by Mishtal with a doctor speaking about the restriction to abortions, a doctor stated that 'We received the news of the [Conscience] Clause with great joy...[many of us] felt that our conscience was being violated because, truth be told, everyone who participated in abortions, or who assisted, be it a doctor or a nurse or an anesthesiologist, acted unethically'67. Mishtal argues that the use of the conscience clause in Poland is so far-reaching as to be considered 'systemic' rather than 'individualistic', significantly impacting the autonomy of women, as well as having implications for their health and societal position 68 . Similarly, in Italy where nearly $70 \%$ of gynaecologists refuse to perform abortion procedures, and the number of doctors relying on conscience clauses in this context rose from $58.7 \%$ to $69.2 \%$ in four years ${ }^{69}$, within this community of practice it may be said that the refusal is a systemic rather than individual one. In this context, then, it is the discourse that abortion should not be permitted that becomes dominant - in a general, unified system of resistance, the dominant discourse is changed from one in which abortion is accepted, yet an individual may refuse to perform it, to one in which an abortion is morally unacceptable and will not be performed by the majority of practitioners. The act is not one of resistance, but a reinforcing of the dominant discourse that pervades that particular power relationship, influencing the decisions made by medical practitioners, or the ability of

\footnotetext{
64 ibid., 42

65 ibid., 44

${ }^{66}$ Joanna Z. Mishtal, 'Matters of "Conscience": The Politics of Reproductive Healthcare in Poland', Medical Anthropology Quarterly 23, no. 2 (2009): 168.

67 Ibid., 169.

68 Ibid., 177.

${ }^{69}$ Christina Zampas and Ximena Andión-Ibañez, 'Conscientious Objection to Sexual and Reproductive Health Services: International Human Rights Standards and European Law and Practice', European Journal of Health Law 19, no. 3 (2012): 248.
} 
women to choose whether to terminate a pregnancy. If conscientious rejection is conceptualised as resistance, then in these instances where the dominant discourse is one of the unacceptable nature of such a procedure, it is those doctors that insist on performing those procedures that may be considered as those acting in resistance to the discourse in which those procedures were performed, as the above doctor stated 'unethically'. The doctor who refuses to perform the procedure is not engaged in conscientious objection, because the existing networks of power affirm and support their decision, in a system and discourse in which the procedure itself is considered as either illegal or inethical. Whether that resistance is considered a form of 'conscientious objection' will ultimately be determined by the society in which that resistance takes place. Conscientious objection, ultimately, constitutes a form of resistance that has been incorporated within the existing networks of power, as they exist at a certain point in time in a determined geographical or cultural location. Where actions serve instead to reinforce those existing power relations, or to exercise power in line with those dominant discourses, those actions cannot be considered as resistance.

\section{Concluding Remarks}

As this article has sought to demonstrate, conscientious objection can be reframed in terms of resistance, demonstrating why certain types of behaviour that are not necessarily condoned by society nevertheless are permitted. In a liberal democracy, in which discourses of freedom, choice and tolerance are dominant and form the basis of the technology of government, permitting acts of individual resistance on the basis of a moral or ethical belief may be permitted both as a way of reinforcing that perception of societal tolerance, as well as acting as a safety-valve that prevents larger, more organised forms of resistance that challenge existing networks of power. The limit to those resistances, and their acceptance as 'conscientious' are ultimately determined by the societal, cultural and historical contexts in which they are exercised, meaning that what is permissible as an act of conscientious objection in one context may be considered as completely unacceptable in another. The extent to which these acts of resistance are considered conscientious will ultimately be determined by the social attitudes and dominant discourses at the time in which they are used. 


\section{References}

Antommaria, Armand H Matheny. 'Adjudicating Rights or Analyzing Interests: Ethicists' Role in the Debate over Conscience in Clinical Practice'. Theoretical Medicine and Bioethics 29, no. 3 (2008): 201-12.

Asch, Adrienne. 'Two Cheers for Conscience Exceptions'. Hastings Center Report NovemberDecember (2006): 11.

Butler, Judith P. Precarious Life: The Power of Mourning and Violence. London: Verso Books, 2004.

Campbell, Mark. 'Commentary: Conscientious Objection and the Council of Europe'. Medical Law Review 19, no. Summer (2011): 467.

Charo, R Alta. 'The Celestial Fire of Conscience - Refusing to Deliver Medical Care'. The New England Journal of Medicine 352, no. 24 (2005): 2471.

Clark, Dylan. 'The Death and Life of Punk, the Last Subculture'. In The Post-Subcultures Reader, edited by David Muggleton and Rupert Weinzierl. New York: Berg, 2003.

Cook, Rebecca J., Mónica Arango Olaya, and Bernard M. Dickens. 'Healthcare Responsibilities and Conscientious Objection'. International Journal of Gynecology \& Obstetrics 104, no. 3 (March 2009): 249-52.

Cook, Rebecca J., and Bernard Dickens. 'Human Rights and Abortion Laws'. International Journal of Gynecology \& Obstetrics 65 (1999): 81.

Curlin, Farr A., Ryan E. Lawrence, Marshall H. Chin, and John D. Lantos. 'Religion, Conscience, and Controversial Clinical Practices'. New England Journal of Medicine 356, no. 6 (2007): 593-600.

Davidson, Laura A., Clare T. Pettis, Amber J. Joiner, Daniel M. Cook, and Craig M. Klugman. 'Religion and Conscientious Objection: A Survey of Pharmacists' Willingness to Dispense Medications'. Social Science and Medicine 71 (2010): 161.

Dean, Mitchell. Governmentality: Power and Rule in Modern Society. 2nd ed. London: SAGE, 2010.

Downing, Lisa. The Cambridge Introduction to Michel Foucault. Cambridge: Cambridge University Press, 2008.

Foucault, Michel. Archaeology of Knowledge. 2nd ed. London: Routledge, 2002.

-_- Power: The Essential Works of Michel Foucault 1954-1984. Edited by James Faubion. Vol. 3. London: Penguin, 2002. 
-_- Power/Knowledge: Selected Interviews and Other Writings, 1972-77. Edited by Colin Gordon. London: Harvester Press, 1980.

- - - Remarks on Marx: - Conversations with Duccio Trombadori. Translated by R. James Goldstein and James Cascaito. New York: Semiotext(e) Foreign Agents, 1991.

-_- Society Must Be Defended: Lectures at the Collège de France, 1975-76. Translated by David Macey. London: Penguin, 2004.

- - - The History of Sexuality Volume 2: The Use of Pleasure. Translated by Robert Hurley. New York: Pantheon, 1985.

Gordon, Colin. 'Governmental Rationality: An Introduction'. In The Foucault Effect: Studies in Governmentality, edited by Graham Burchell, Colin Gordon, and Peter Miller. Chicago: University of Chicago Press, 1991.

Haas, Peter M. 'Introduction: Epistemic Communities and International Policy Coordination'. International Organization 46, no. 1 (1 January 1992): 1-35.

Harvey, David. 'Neoliberalism as Creative Destruction'. The ANNALS of the American Academy of Political and Social Science 610, no. 1 (3 January 2007): 21-44.

Kelly, Mark G. E. The Political Philosophy of Michel Foucault. London: Routledge, 2012.

Keown, John. Abortion, Doctors, and the Law: Some Aspects of the Legal Regulation of Abortion in England from 1803 to 1982. Cambridge; New York: Cambridge University Press, 1988.

Lave, Jean, and Etienne Wenger. Situated Learning: Legitimate Peripheral Participation. Cambridge [England]; New York: Cambridge University Press, 1991.

Lemke, Thomas. Foucault, Governmentality, and Critique. Colorado: Paradigm, 2011.

Miller, Peter, and Nikolas Rose. Governing the Present: Administering Economic, Social and Personal Life. Cambridge: Polity Press, 2008.

Mishtal, Joanna Z. 'Matters of "Conscience": The Politics of Reproductive Healthcare in Poland'. Medical Anthropology Quarterly 23, no. 2 (2009): 161-83.

Robertson, John A. Children of Choice: Freedom and the New Reproductive Technologies. Princeton: Princeton University Press, 1994.

Savulescu, Julian. 'Conscientious Objection in Medicine'. British Medical Journal 332 (2006): 294.

Shiner, Larry. 'Reading Foucault: Anti-Method and the Genealogy of Power-Knowledge'. History and Theory 21, no. 3 (1 October 1982): 382-98. 
Thomson, Michael. 'Abortion Law and Professional Boundaries'. Social and Legal Studies 22 (2013): 191.

Vischer, Robert K. 'Individual Rights vs. Institutional Identity: The Relational Dimension of Conscience in Health Care'. Ave Maria Law Review 9 (2010): 67.

Wicclair, Mark R. 'Conscientious Objection in Medicine'. Bioethics 14, no. 3 (2000): 205-27.

- - - 'Is Conscientious Objection Incompatible with a Physician's Professional Obligations?' Theoretical Medicine and Bioethics 29, no. 3 (2008): 171-85.

Yoder, P Stanley, Papa Ousmane Camara, and Baba Soumaoro. Female Genital Cutting and Coming of Age in Guinea. Conakry, Guinea, December 1999. Conakry, Guinea.

Zampas, Christina, and Ximena Andión-Ibañez. 'Conscientious Objection to Sexual and Reproductive Health Services: International Human Rights Standards and European Law and Practice'. European Journal of Health Law 19, no. 3 (2012): 231-56. 